\title{
The Determination of Normal Percentages of Syncytiotrophoblastic Knots in Various Regions of Placenta: Where to Count the Syncytial Knots
}

\author{
Sinsityotrofoblastik Düğümlerin Plasentanın Farklı Bölgelerindeki \\ Normal Yüzdelerinin Belirlenmesi: Sinsityal Düğümleri Nereden Sayalım
}

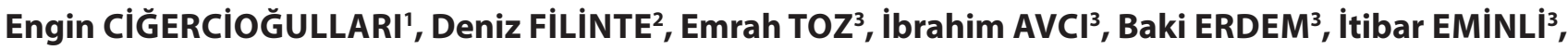 \\ Taner ÖZGÜR ${ }^{4}$
}

\begin{abstract}
Department of Pathology, 'Ağrı Women and Children's Hospital, AĞRI, TURKEY, ${ }^{2}$ Marmara University, School of Medicine, iSTANBUL, TURKEY,
${ }^{3}$ Division of Obstetrics and Gynecology, Ağrı Women and Children's Hospital, AĞRI, TURKEY, ${ }^{4}$ Department of Pediatrics,
\end{abstract} Uludağ University, School of Medicine, BURSA, TURKEY

\begin{abstract}
Objective: The marginal, basal and subchorial regions of the placenta are considered to be more hypoxic than other regions. Therefore, it is not recommended to determine the increase in syncytiotrophoblast knots, based on the major morphological change in placental hypoxia, from the samples taken from these regions. However, the normal count of knots at various regions of placenta is not investigated.

Material and Method: In this study we have sampled morphologically and clinically normal placenta with eccentric cord insertion from various sites, either close to cord entrance or away from it (marginal, non-marginal basal, non-marginal subchorial, and nonmarginal midparanchymal). The number of knots was calculated on a total of at least 100 villi for each placental sample. The normal amount of knots in different regions and comparison between them were investigated. Twenty-eight placentas with eccentric cord insertion were sampled in the same manner. Hot spots from the above mentioned regions were counted in a total of 100 villi.
\end{abstract}

Results: No significant difference was found between the dual comparison of the mean percentages of different regions ( $\mathrm{p}$ : 0.148). The variety of hypoxia in different regions of the placenta could not be demonstrated in this study.

Conclusion: It is found that there is no difference in perfusion that can be morphologically demonstrated with increase in syncytiotrophoblast knot, between different regions of placenta.

Key Words: Hypoxia, Placenta, Syncytiotrophoblast

\section{ÖZ}

Amaç: Plasentanın marjinal, bazal ve subkoryal bölgelerinin diğer bölgelerine göre daha hipoksik olduğu düşünülür. Buna göre, plasental hipoksideki morfolojik bulgular temelinde sinsityotrofoblastik düğümlerdeki artışın bu bölgelerden alınacak örneklerden belirlenmesi önerilmez. Her șeye karșın plasentanın farklı bölgelerindeki düğümlerin normal sayısı incelenmemiştir.

Gereç ve Yöntem: Bu çalışmada, eksantrik kord girişli, morfolojik ve klinik açıdan normal plasentaların kord girişine yakın veya uzak, farklı alanlarından (marjinal, non-marjinal bazal, nonmarjinal-subkoryal, non-marjinal midparenkimal) örnekler alındı. Dügümler, her bir plasental örnekte total en az 100 villüsten sayıldı. Farklı bölgelerdeki normal dügüm sayısı incelendi ve karşılaştırma yapıldı. Eksantrik kord girişli 28 plasenta benzer biçimde örneklendi. Yukarıda belirtilen bölgelerdeki sıcak noktalar total 100 villüsten sayıldı.

Bulgular: Farklı bölgelerin ortalama yüzdeleri dual karșılaștırıldığında anlamlı bir fark saptanmadı (p: 0,148). Bu çalışmada, plasentanın farklı bölgelerindeki hipoksi değişiklikleri gösterilemedi.

Sonuç: Yazarların düşüncesine göre plasentanın farklı bölgelerinde sinsityotrofoblastik düğüm artışı ile morfolojik olarak gösterilebilecek perfüzyon farklılıkları bulunmamaktadır.

Anahtar Sözcükler: Hipoksi, Plasenta, Sinsityotrofoblast

Correspondence: Engin CİĞERCİOĞULLARI

Ağrı Kadın Doğum ve Çocuk Hastalıkları Hastanesi

Hürriyet Mah. Yaşar Eryılmaz Cad. 04100 Ağrı, TURKEY

E-mail: ecigerciogullari@yahoo.com Phone: + 905334468091 


\section{INTRODUCTION}

Tenney Parker Changes (TPC) are the major marker of maternovascular perfusion insufficiency. They are characterized by syncytial knot increase and villus clustering. Syncytial knot is a marked clustering of the syncytial nuclei under the light microscope. Studies performed with the electron microscope demonstrate various types of syncytial knots with different mechanisms of formation. These formation types usually cannot be differentiated under the light microscope. The syncytial knot increase has histomorphological significance (1). There is ongoing research among pathologists to designate the most appropriate definition of syncytial knots (2). The existence of syncytial knots in more than one third of the villi is defined as TPC. It is recommended to calculate the knot number from the midparenchymal region, because the basal, marginal and the subchorial regions are considered to be more hypoxic than the other regions (3). However, there is no standard regarding the normal number of knots from different regions. This study attempts to determine the normal amount of syncytial knots in different regions and to demonstrate whether a difference exists between them.

\section{MATERIALS and METHODS}

Twenty-eight placentas received at Ağrı Women and Children's Hospital, Department of Pathology were chosen for the study. All the samples were term gestational placentas with eccentric cord entrances. The weight of the placentas varied between 414 and 470 grams, which was within normal limits (4). They were all reported as late 3rd trimester placentas that were morphologically normal. Descriptive additional diagnoses coexisted which did not affect the final diagnosis. The following cases thought to bias the study either clinically or morphologically were not included in the study;

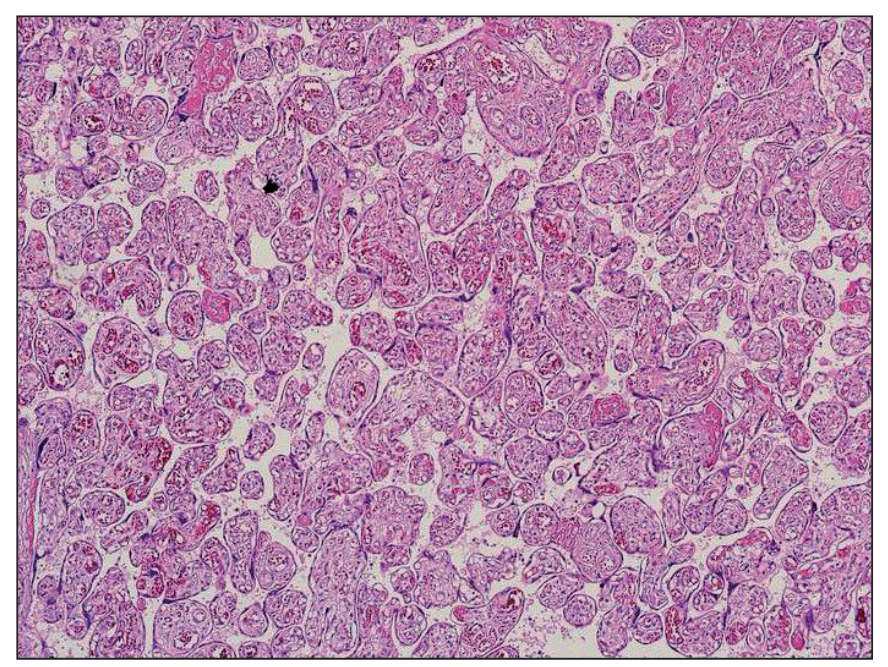

Figure 1: Score 22 (Villous maturation score) (H\&E; x100).
- Cases with no eccentric entrances: central, marginal and other cord entrances were thought to have different perfusions than eccentric ones.

- Placenta-induced hypertension (PIH): It is reported that there is no uniform physiologic change in different vessels of decidua basalis and in various regions of a single vessel as well (3). That is why it is accepted that even normal placentas may demonstrate physiological conversion insufficiency that is frequently seen in cases with preeclampsia and SGA (Small for Gestational Age) (5). As the deficiency of physiological conversion may increase the perfusion variances in the placenta, PIH cases with normal morphology were excluded from the study.

- Cases with villous maturation score of other than 22 and 23: Villous maturation scores are included in the reports of our department. The scores of 22 and 23 are defined as normal late third trimester placentas as demonstrated by Benirske and Kaufmann (1) and shown in Figure 1 and Figure 2.

- Cases with chorioamnionitis: The endothelin amount is increased in chorioamnionitis which in turn results in fetal vasoconstriction and hypoperfusion (6). VEGF is a growth factor increasing inflammatory cell migration. Its expression is increased both in hypoxic cases and in chorioamnionitis $(7,8)$. Chorioamnionitis cases were therefore excluded from the study even with scores of 22 and 23.

- Cases with morphological changes associated with hypoxia and decreased perfusion: TPC is not the single finding of hypoxia and cases with the following changes demonstrated even focally were therefore excluded from the study: Increased intervillous fibrin, distal villous hypoplasia, acute atherosis, mural hypertrophy of membrane arterioles, muscularised basal plate arteries, increased placental side giant cells, increased immature intermediate trophoblasts,

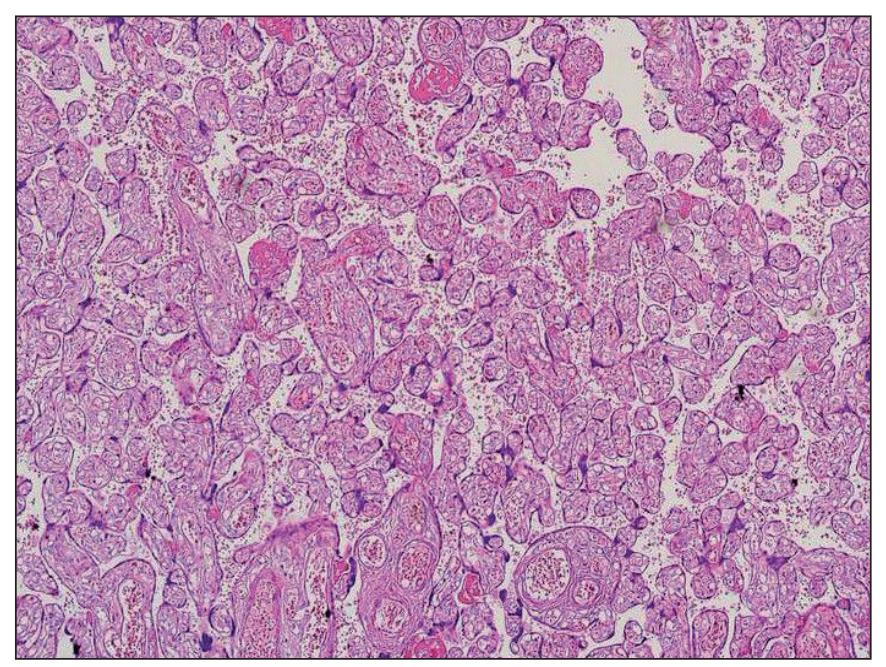

Figure 2: Score 23 (Villous maturation score) (H\&E; x100). 
thin umbilical cord, laminar necrosis, and microscopic chorionic pseudo cysts $(2,9,10)$.

Placentas were kept in a solution of $10 \%$ formaldehyde for a night and were cut into two segments from the cord entrance parallel to its longitudinal axis (Figure 3). Six blocks were taken from each case. The sampling regions were as follows;

1X: Marginal zone close to cord insertion.

1: Non-marginal zone close to cord insertion.

2: Non-marginal zone far from cord insertion.

2X: Marginal zone far from cord insertion (Figure 4).

O: Fetal membranes and cord.

T: Horizontally sampled placental base.

After this sampling, the placentas were dissected parallel to the first incision and additional samples were taken from

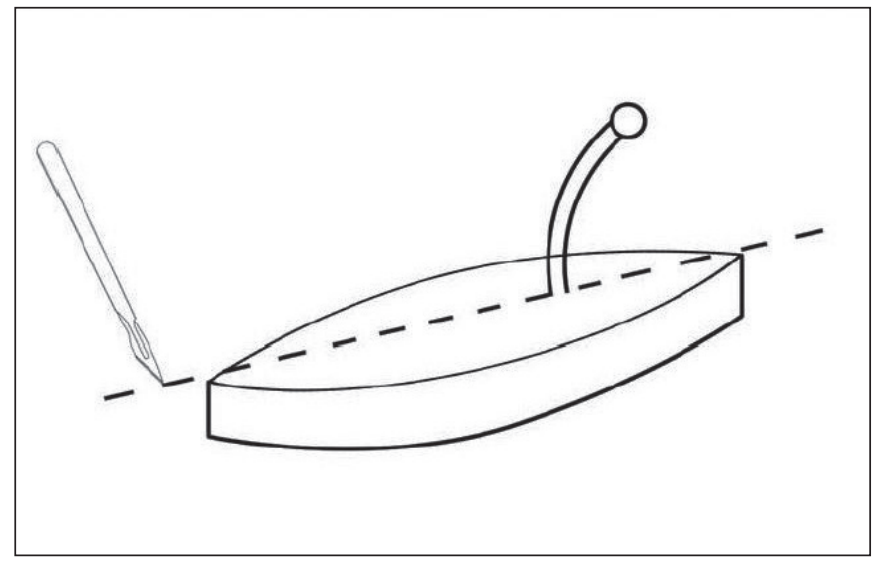

Figure 3: The dissection of placenta in this study.

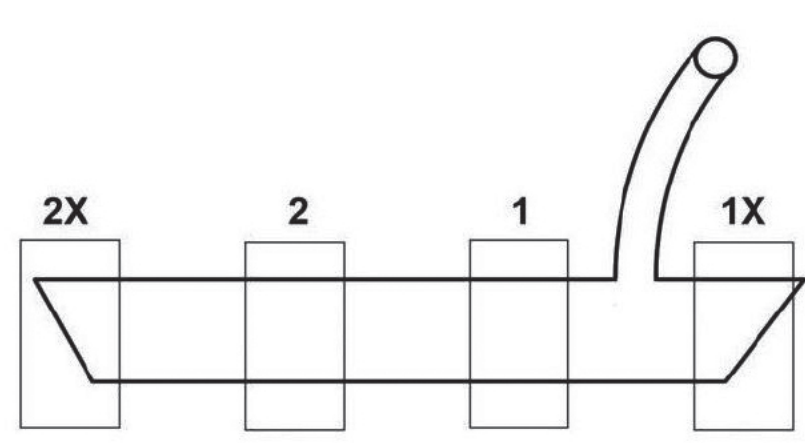

Figure 4: Illustration of zones sampled in the study. 1X, marginal zone close to cord insertion; $2 \mathrm{x}$, marginal zone far from cord insertion; 1 , central zone close to cord insertion; 2 , central zone far from cord insertion. regions with an unusual appearance. In order to increase the standardization in perfusion, the central regions of maternal cotyledons at the opening site of the uterine arteries were chosen. All the samples were cut in 5 micron thickness and stained with hematoxylin and eosin. The pathologist investigated the samples. All the counting was done from the hot spots and knot numbers were determined from at least 100 villi for each dissected sample. Each syncytial knot and syncytial knot bridging was calculated as 1 point. During these scorings, accumulations with crowded nuclei, which are easily seen in 10x magnifications, were counted without question. For smaller knots, the inclusion presence of at least 6 nuclei was required. The compact accumulation of the nuclei was stipulated. Only the knots on terminal villi were counted. Syncytial knots existing on more than 1 villus due to slicing were also included in the study if they met the criteria above. Each syncytial knot was scored as 1 . Syncytial knots including at least 6 nuclei and combining more than two villi were defined as syncytial knot bridging. Each syncytial knot bridging was scored as 1 .

When the intense regions were selected, the regions closest to the choriobasal unit in the marginal regions were preferred for counting. For subchorial counting the closest regions to chorial plaque, for midparenchymal counting the $1 / 3$ sectional part of the placental thickness, and for basal counting the closest regions to the basal plaque were preferred. SPSS version 16.0 Statistical Analysis Software was used to analyze the relation between variants. Variations among groups were determined using the Mann-Whitney $\mathrm{U}$ test. The Kruskal-Wallis test was used for comparison of more than two groups. Probabilities of less than or equal to 0.05 were accepted as significant.

\section{RESULTS}

The clinical and pathological characteristics (the type of birth, the direction of cord turn, additional microscopic characteristics and villous maturation scores) of the 28 cases included in the study are demonstrated in Table I.

Villus counting from the previously defined regions, their number of included syncytial knots present, and the percentages of these are demonstrated in Table II. The group statistics are listed in Table III and Table IV. Mean parameters were calculated for every region. No significant difference between the mean parameters of the regions were demonstrated with Kruskal-Wallis test (p:0.148). No significant difference between the mean parameters of regions close to and away from cord entrance were found ( $\mathrm{p}: 0.101$, and p:0.282, respectively). No significant differences between the mean parameters of marginal, subchorial, basal, and midparenchymal counting of regions close to and away from cord entrance were found ( $\mathrm{p}: 0,594$, p:0,706, p:0,577, and p:0,577 respectively). 
Table I: The clinical and pathological characteristic of cases used in this study

\begin{tabular}{|c|c|c|c|c|}
\hline & Delivery route & Cord turn & Additional microscopical features & VMS \\
\hline 1 & VD & $\mathrm{L}$ & $\mathrm{x}$ & 22 \\
\hline 2 & $\mathrm{C} / \mathrm{S}$ & $\mathrm{L}$ & $\mathrm{x}$ & 23 \\
\hline 3 & $\mathrm{C} / \mathrm{S}$ & $\mathrm{L}$ & Focal stem villus calcification & 22 \\
\hline 4 & VD & $\mathrm{L}$ & $\mathrm{x}$ & 23 \\
\hline 5 & VD & $\mathrm{R}$ & Cylindric change in amnion epithelium & 22 \\
\hline 6 & $\mathrm{C} / \mathrm{S}$ & $\mathrm{L}$ & Subcorial fibrinoid excess & 23 \\
\hline 7 & $\mathrm{C} / \mathrm{S}$ & $\mathrm{L}$ & $\mathrm{x}$ & 22 \\
\hline 8 & $\mathrm{C} / \mathrm{S}$ & $\mathrm{R}$ & Amniotic epithelium proliferation & 22 \\
\hline 9 & $\mathrm{C} / \mathrm{S}$ & $\mathrm{R}$ & $\mathrm{x}$ & 22 \\
\hline 10 & $\mathrm{C} / \mathrm{S}$ & $\mathrm{L}$ & Amniotic mesencymal pigmented macrophages & 23 \\
\hline 11 & $\mathrm{C} / \mathrm{S}$ & $\mathrm{L}$ & $\mathrm{x}$ & 22 \\
\hline 12 & VD & $\mathrm{L}$ & $\mathrm{x}$ & 22 \\
\hline 13 & $\mathrm{C} / \mathrm{S}$ & $\mathrm{L}$ & Ductus vitellus remnant & 22 \\
\hline 14 & $\mathrm{C} / \mathrm{S}$ & $\mathrm{L}$ & $\mathrm{x}$ & 22 \\
\hline 15 & $\mathrm{C} / \mathrm{S}$ & $\mathrm{L}$ & $\mathrm{x}$ & 22 \\
\hline 16 & $\mathrm{C} / \mathrm{S}$ & $\mathrm{L}$ & $\mathrm{x}$ & 22 \\
\hline 17 & VD & $\mathrm{L}$ & $\mathrm{x}$ & 22 \\
\hline 18 & $\mathrm{C} / \mathrm{S}$ & $\mathrm{L}$ & Intravillous fibrinoid excess & 22 \\
\hline 19 & $\mathrm{C} / \mathrm{S}$ & $\mathrm{L}$ & $\mathrm{x}$ & 22 \\
\hline 20 & $\mathrm{C} / \mathrm{S}$ & $\mathrm{L}$ & $\mathrm{x}$ & 22 \\
\hline 21 & $\mathrm{C} / \mathrm{S}$ & $\mathrm{L}$ & Subcorial focal chronic infarct & 22 \\
\hline 22 & $\mathrm{C} / \mathrm{S}$ & $\mathrm{L}$ & $\mathrm{x}$ & 22 \\
\hline 23 & $\mathrm{C} / \mathrm{S}$ & $\mathrm{L}$ & $\mathrm{x}$ & 22 \\
\hline 24 & $\mathrm{C} / \mathrm{S}$ & $\mathrm{R}$ & $\mathrm{x}$ & 22 \\
\hline 25 & VD & $\mathrm{R}$ & $\mathrm{x}$ & 22 \\
\hline 26 & $\mathrm{C} / \mathrm{S}$ & $\mathrm{R}$ & $\mathrm{x}$ & 22 \\
\hline 27 & $\mathrm{C} / \mathrm{S}$ & $\mathrm{R}$ & $\mathrm{x}$ & 22 \\
\hline 28 & $\mathrm{C} / \mathrm{S}$ & $\mathrm{L}$ & $\mathrm{x}$ & 23 \\
\hline
\end{tabular}

C/S: Cesarean section, VD: Vaginal Delivery, VMS: Villous maturation score.

\section{DISCUSSION}

A syncytial knot, primarily defined under the light microscope, is defined as significant clustering of syncytial nuclei (Figure 5). Increase in syncytial knots and clustering of villus are defined as Tenney Parker Changes (TPC). TPC are primarily described as the determinant of preeclampsia. They are attributed to demonstrate placental ischemia later on. They have been associated with Factor 5 mutations lately $(11,12)$. Syncytial knots are classified into three categories according to their mechanisms of formation. However, differentiation of these under the light microscope is quite difficult $(1,13)$. Instead of being trophoblastic proliferations, most of the knots appear as slice artifacts of deformed villi due to villous angiogenesis, specifically during the last trimester. However, whatever their etiologies are, syncytial knots are known to demonstrate changes in trophoblastic turnover (3). Syncytial knots and bridging have various definitions in different studies. Baergen et al. have defined syncytial knots as clusters of 5 or more nuclei and only in terminal villi (14). However, it is reported that some of the counted villi do not meet the criteria and possess less than 5 nuclei. Syncytial bridging is described as one of the 4 etiological types of syncytial knots and the real bridging is described as a rare condition originating from fusion of 2 villi. The contact of the surfaces of the chorionic villi is designated as "touching" in the same study. Syncytial knots are defined as an increase in syncytiotrophoblastic nuclei, and the bridging as villous agglutination in the study of Redline et al. According to this, villous agglutination is 


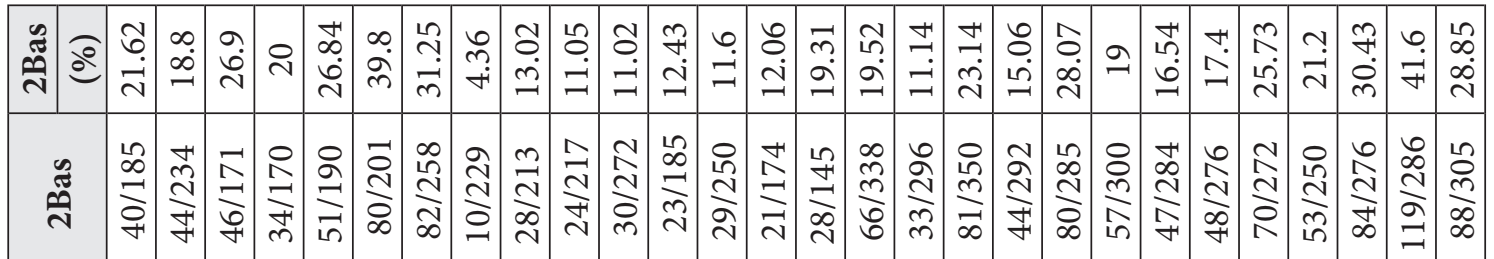

J

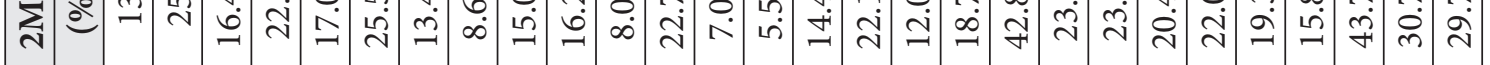

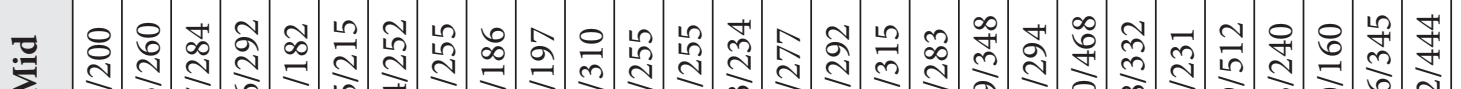

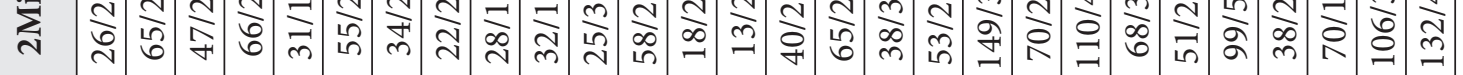

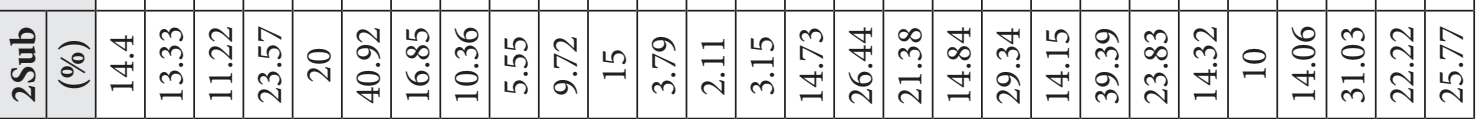

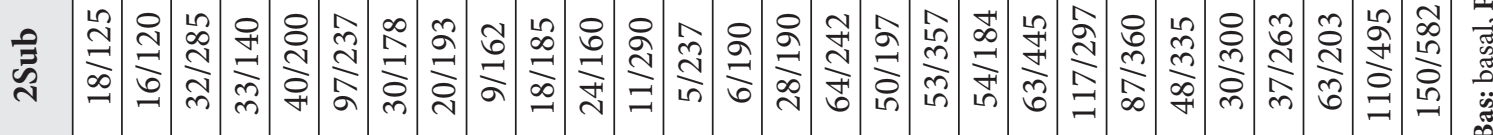

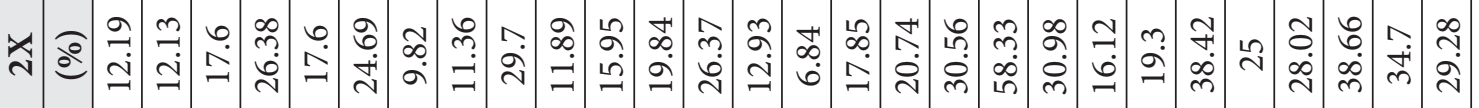

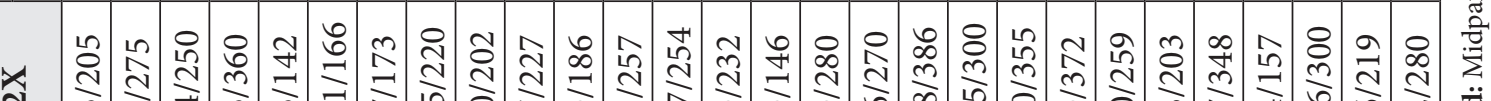

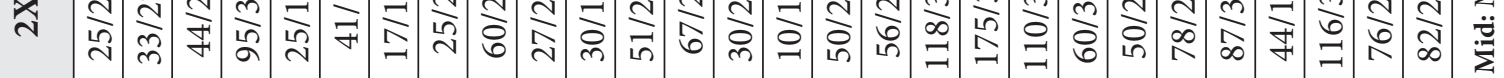

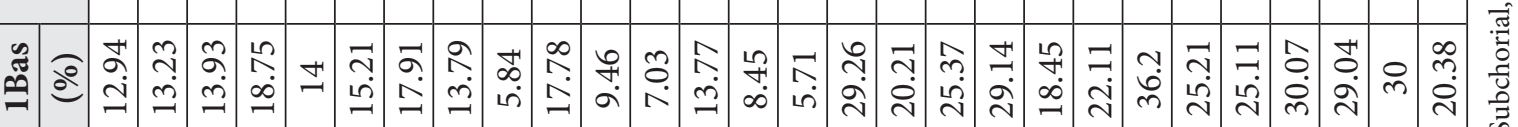

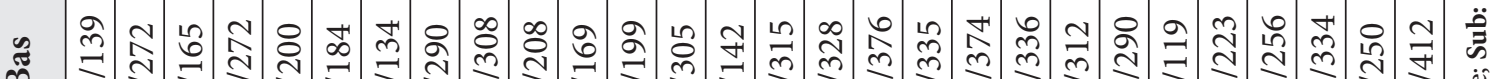

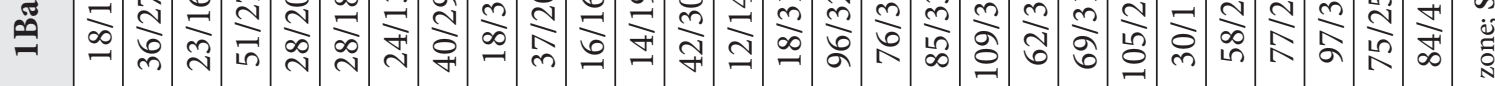

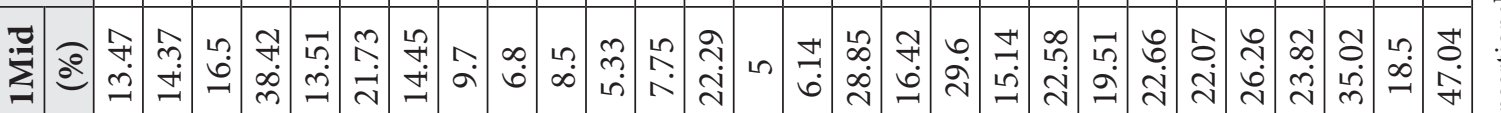

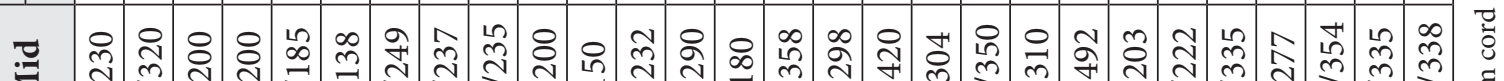

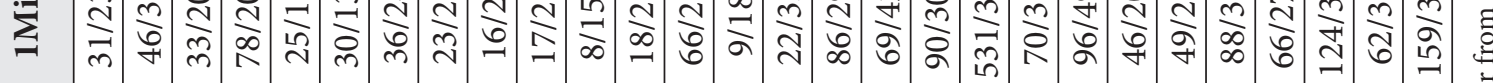

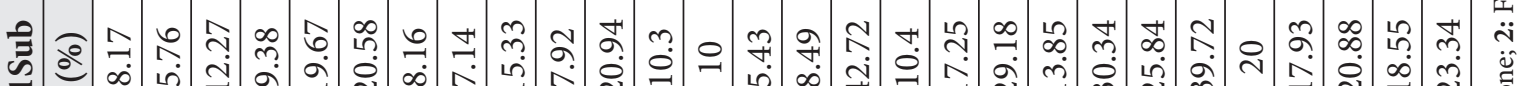

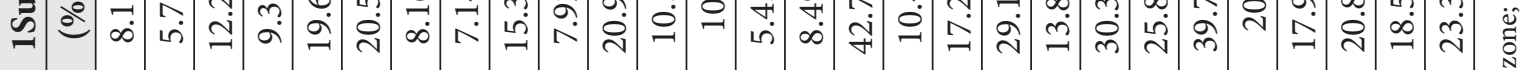

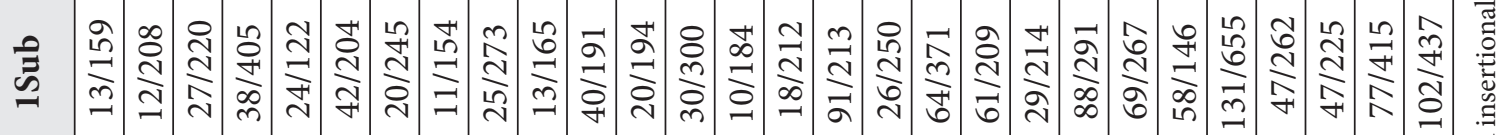
×

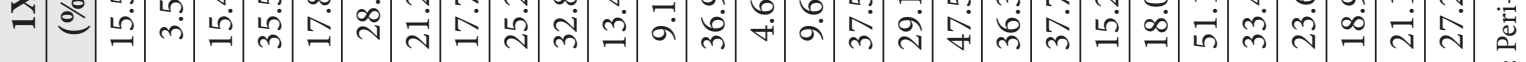

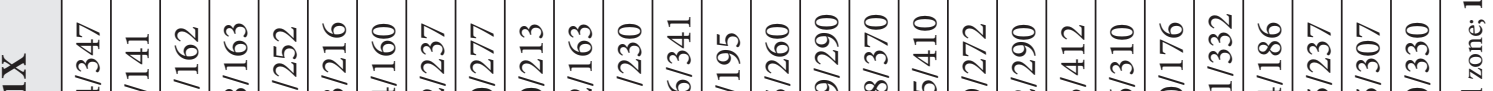

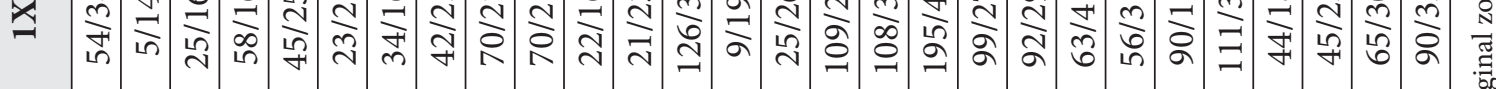

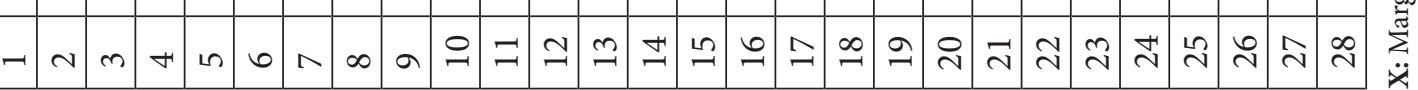


Table III: Group Statistics; mean percentages of various areas and their comparison between peri-cord insertional and far from cord insertional zones

\begin{tabular}{|c|c|c|c|c|c|c|}
\hline \multicolumn{2}{|c|}{ Area } & $\mathbf{n}$ & Mean percentage & SD & Std. error mean & $\mathbf{p}$ \\
\hline \multirow{2}{*}{$\mathrm{x}$} & 1 & 28 & 24.46 & 12.24 & 2.31 & \multirow{2}{*}{0.594} \\
\hline & 2 & 28 & 22.97 & 11.17 & 2.11 & \\
\hline \multirow{2}{*}{ sub } & 1 & 28 & 17.12 & 9.78 & 1.84 & \multirow{2}{*}{0.706} \\
\hline & 2 & 28 & 17.55 & 9.96 & 1.88 & \\
\hline \multirow{2}{*}{ bas } & 1 & 28 & 18.86 & 8.31 & 1.57 & \multirow{2}{*}{0.577} \\
\hline & 2 & 28 & 20.63 & 8.89 & 1.68 & \\
\hline \multirow{2}{*}{$\operatorname{mid}$} & 1 & 28 & 18.97 & 10.38 & 1.96 & \multirow{2}{*}{0.606} \\
\hline & 2 & 28 & 19.85 & 9.25 & 1.74 & \\
\hline
\end{tabular}

Table IV: Group Statistics; comparison between mean percentages of various areas (x, sub,bas, mid) within peri-cord insertional (1) and far from cord insertional (2) zones

\begin{tabular}{|c|c|c|c|c|c|c|}
\hline \multicolumn{2}{|c|}{ Area } & $\mathbf{n}$ & Mean percentage & SD & Std. error & $\mathbf{p}$ \\
\hline \multirow{5}{*}{1} & $\mathrm{x}$ & 28 & 24.46 & 12.24 & 2.31 & \multirow{5}{*}{0.101} \\
\hline & sub & 28 & 17.12 & 9.78 & 1.84 & \\
\hline & bas & 28 & 18.86 & 8.31 & 1.57 & \\
\hline & mid & 28 & 18.97 & 10.38 & 1.96 & \\
\hline & Total & 112 & 19.85 & 10.50 & 0.99 & \\
\hline \multirow{5}{*}{2} & $\mathrm{X}$ & 28 & 22.97 & 11.17 & 2.11 & \multirow{5}{*}{0.282} \\
\hline & Sub & 28 & 17.55 & 9.96 & 1.88 & \\
\hline & Bas & 28 & 20.63 & 8.89 & 1.68 & \\
\hline & Mid & 28 & 19.85 & 9.25 & 1.74 & \\
\hline & Total & 112 & 20.25 & 9.91 & 0.93 & \\
\hline
\end{tabular}

described as clustering of the adjacent distal villi ( $>2$, $<20$ ) inside fibrin and/or bridging (micro infarcts) at the syncytial knots (2). Others have mentioned that the formation of syncytial knots and bridging are slicing artifacts due to deformed villi with vascular proliferations, and the syncytial knots and the bridging are not defined as separate forms (1). We have scored one, two, or more villi including significant knot accumulation as 1 in our study. Syncytial knots or bridging are not differentiated. Some of these were proposed to be the contact regions described by Baergen et al. (14). The real and the pseudo bridging, and the differences from the contact regions should be clearly defined in future studies.

The determination of the region where the counting will take place is another argument. While in Handbook of Placental Pathology eds. Faye-Peterson OM, Heler DS, Joshi recommends counting from the midparenchymal region and from the knots on terminal villi (3), another study suggests the slice to be taken from the $75 \%$ of the basal part and from the knots on proximal stem villi and distal villi (2).

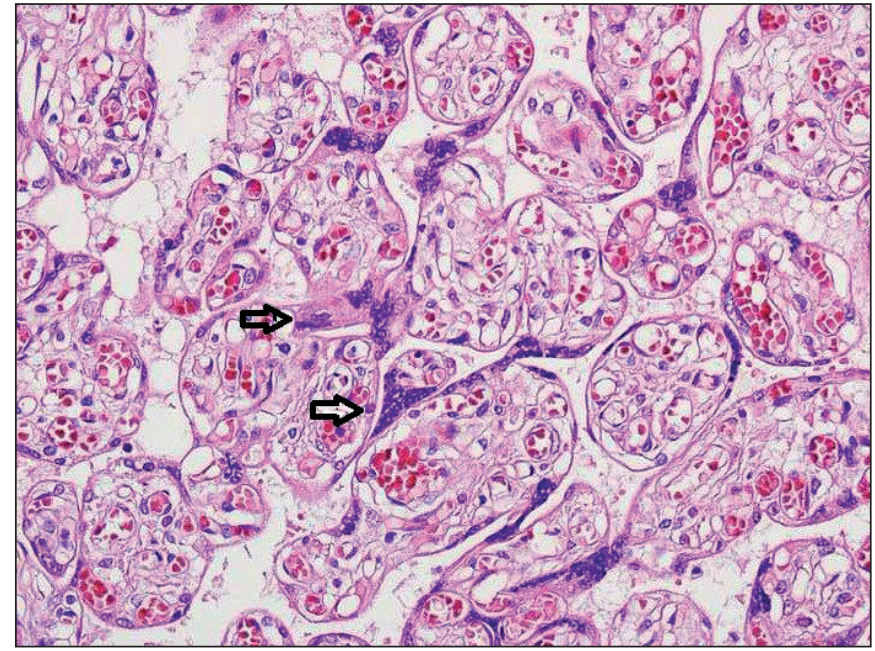

Figure 5: Syncytial Knots (Arrows) (H\&E; x200). 
Relative ischemia of marginal parts and the non-marginal parts of the basal and subchorial areas of the normal placentas have been reported (3). This thesis constitutes the basis of our study and our goals were to differentiate various areas according to their number of syncytial knots, and if there is a difference, to support the idea of relative ischemia and to contribute to the standardization of normal number of syncytial knots in various regions.

The theory of relative ischemia stems from physiological data about maternal circulation. The blood from the transformed arterioles entering the maternal circulation spouts into the subchorial region. This results in a fibrinoid accumulation defined as "subchorionic fibrinoid" and returns back to the basal area. It is reabsorbed from the open-ended veins (3). That is why the subchorial and the basal areas are the locations of blood accumulation. Another study has hypothesized that the collateral arterial circulation and the gestational arterial changes are fewer in the marginal regions (15). Besides, lesions like infarcts and $\mathrm{x}$ cell cysts that are classically known to be associated with hypoxia are reported to be more frequently seen in subchorial, basal and marginal regions.

No significant differences between the number of syncytial knots in any region were observed in our study. Although there is no significant increase in the number of syncytial knots in the marginal area or decrease in nonmarginal basal zones, these results should not be interpreted as nonexistence of relative ischemia, as the minor changes in perfusion may not effect the morphology. The increase in syncytial knot number is not the only finding of hypoxia and does not necessarily coexist with the other morphological changes of hypoxia. The morphological findings of hypoxia vary according to the degree and onset of hypoxia (1619). For example, TPC may not accompany chorioangiosis that is thought to be formed due to long-lasting low grade hypoxia (3). Although we have excluded the cases with known hypoxia-associated changes from our study, there may be other findings yet not defined and associated with hypoxia. Future studies are needed to clarify this issue. We have an ongoing study proposed to demonstrate the number of syncytial knots from the same regions used in this study and investigate from where the knot increase has started, in cases with a villous maturation score of 32 .

As a conclusion no differences between the number of syncytial knots counted from various regions of the normal term human placenta are demonstrated. The thesis of increased ischemia in marginal, non-marginal basal and non-marginal subchorial regions of the term, clinically and morphologically normal placentas are not supported in this study.

\section{ACKNOWLEDGEMENTS}

We thank Dr. Esin Kotiloglu Kara for her contributions.

\section{REFERENCES}

1. Classification of villous maldevelopment, basic structure of villous trees, architecture of normal villous trees, villous maturation score. In: Benirschke K, Kaufmann P, Baergen R, editors. Pathology of the Human Placenta. 5th ed. New York: Springer, 2006.

2. Redline RW, Boyd T, Campbell V, Hyde S, Kaplan C, Khong TY, Prashner HR, Waters BL; Society for Pediatric Pathology, Perinatal Section, Maternal Vascular Perfusion Nosology Committee. Maternal vascular underperfusion: Nosology and reproducibility of placental reaction patterns. Pediatr Dev Pathol. 2004;7:237-49.

3. Faye-Peterson OM, Heler DS, Joshi VV. Histologic lesions of the placenta, Gross abnormalities of the placenta, Structure of the placenta. In: Handbook of Placental Pathology. 2nd Ed. London and New York: Taylor\&Francis Group, 2006, 33-108.

4. Kalousek DK, Dimmick JE. Pathology of spontaneous abortions and chromosomal abnormalities in stillbirth and neonatal death. In: Dimmick JE, Kalousek DK, editors. Developmental pathology of the embryo and fetus. Philadelphia: JB Lippincott; 1992. 55110 .

5. Aardema MW, Oosterhof H, Timmer A, van Rooy I, Aarnoudse JG. Uterine artery Doppler flow and uteroplacental vascular pathology in normal pregnancies and pregnancies complicated by preeclampsia and small for gestational age fetuses. Placenta. 2001;5:405-11.

6. Altshuler G. Role of the placenta in perinatal pathology. Pediatr Pathol Lab Med. 1996;16:207-33.

7. Banita M, Pisoschi C, Caruntu ID, Stanciulescu C, Cernea N Immunohistochemical study of the morphological changes in placental villi from fetal membranes infectious disease. Rev Med Chir Soc Med Nat Iasi. 2007;4-6:464-71.

8. Kumazaki K, Nakayama M, Suehara N, Wada Y. Expression of vascular endothelial growth factor, placental growth factor, and their receptors Flt-1 and KDR in human placenta under pathologic conditions. Hum Pathol. 2002;11:1069-77.

9. Stanek J, Weng E. Microscopic chorionic pseudocysts in placental membranes: A histologic lesion of in uterohypoxia. Pediatr Dev Pathol. 2007;5-6:192-8.

10. Goldenberg RL, Faye-Petersen O, Andrews WW, Goepfert AR, Cliver SP, Hauth JC. The Alabama Preterm Birth Study: Diffuse decidual leukocytoclastic necrosis of the decidua basalis, a placental lesion associated with preeclampsia, indicated preterm birth and decreased fetal growth. J Matern Fetal Neonatal Med. 2007;5:391-5.

11. Tenney B, Parker, F. The pathology in toxemia of pregnancy. Amer J Obstet Gynecol. 1940;39:1000-5.

12. Rogers BB, Momirova V, Dizon-Townson D, Wenstrom K Samuels P, Sibai B, Spong C, Caritis SN, Sorokin Y, Miodovnik M, O'Sullivan MJ, Conway D, Wapner RJ. Avascular villi, increased syncytial knots, and hypervascular villi are associated with pregnancies complicated by factor V Leiden mutation. Pediatr Dev Pathol. 2010;13:341-7. 
13. Cantle SJ, Kaufmann P, Luckhardt M, Schweikhart G. Interpretation of syncytial sprouts and bridges in the human placenta. Placenta. 1987;8:221-34.

14. Loukeris K, Sela R, Baergen RN. Syncytial knots as a reflection of placental maturity: Reference values for 20 to 40 weeks' gestational age. Pediatr Dev Pathol. 2010;13:305-9.

15. Becroft DM, Thompson JM, Mitchell EA. Placental infarcts, intervillous fibrin plaques, and intervillous thrombi: Incidences, co occurrences, and epidemiological associations. Pediatr Dev Pathol. 2004;1-2:26-34.

16. Stanek J. Acute and chronic placental membrane hypoxic lesions. Virchows Arch. 2009;10:315-22.

17. Suzuki K, Itoh H, Kimura S, Sugihara K, Yaguchi C, Kobayashi Y, Hirai K, Takeuchi K, Sugimura M, Kanayama N. Chorangiosis and placental oxygenation. Congenit Anom (Kyoto). 2009;49: 71-6.

18. Akbulut M, Sorkun HC, Bir F, Eralp A, Duzcan E. Chorangiosis: The potential role of smoking and air pollution. Pathol Res Pract. 2009;205:75-81.

19. Redline RW, Patterson P. Preeclampsia is associated with an excess of proliferative immature intermediate trophoblast. Hum Pathol. 1995;6:594-600. 